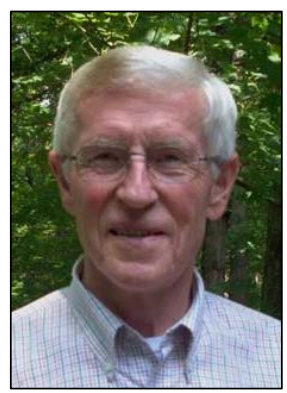

\author{
The EConomic Pamphleteer \\ JOHN IKERD
}

\title{
Rethinking government policies for growing farmers
}

Published online August 2010

Copyright (C) 2010 by New Leaf Associates, Inc.

"We can't solve problems by using the same kind of thinking that created them." At no time have these oft-quoted words of Albert Einstein been more appropriate than in addressing the problems of today's farmers. Between 1940 and 1990, with the industrialization of agriculture, the number of

Why did I name my column "The Economic

Pamphleteer"? Pamphlets historically were short, thoughtfully written opinion pieces and were at the center of every revolution in western history. Current ways of economic thinking aren't working and aren't going to work in the future. Nowhere are the negative consequences more apparent than in foods, farms, and communities. I know where today's economists are coming from; I have been there. I spent the first half of my 30-year academic career as a very conventional free-market, bottom-line agricultural economist. I eventually became convinced that the economics I had been taught and was teaching wasn't good for farmers, wasn't good for rural communities, and didn't even produce food that was good for people. I have spent the 25 years since learning and teaching the principles of a new economics of sustainability. Hopefully my "pamphlets" will help spark a revolution in economic thinking. farms in the U.S. dropped from more than six million to just over two million. This drop in the number of farms has since leveled off, but the ability of farms to support farm families has continued to decline. Over the past couple of decades, around 90 percent of farm family income has come from nonfarm sources.

\footnotetext{
John Ikerd is professor emeritus of agricultural economics, University of Missouri, Columbia. He was raised on a small dairy farm in southwest Missouri and received his $B S, M S$, and Ph.D. degrees in agricultural economics from the University of Missouri. He worked in private industry for a time and spent 30 years in various professorial positions at North Carolina State University, Oklahoma State University, University of Georgia, and the University of Missouri before retiring in 2000. Since retiring, he spends most of his time writing and speaking on issues related to sustainability with an emphasis on economics and agriculture. Ikerd is author of Sustainable Capitalism; A Return to Common Sense; Small Farms Are Real Farms; Crisis and Opportunity: Sustainability in American Agriculture; and, just published, A Revolution of the Middle. More background and selected writings are at http://web.missouri.edu/ ikerdj.
} 
In spite of all of the political rhetoric about supporting family farms, government farm programs have consistently subsidized the industrialization of agriculture. As a consequence, farm programs have contributed both directly and indirectly to the demise of family farms. Subsidized, standardized, routinized, and simplified farm management has effectively coerced or forced fewer farmers on larger farms to produce more food at ever lower economic costs. However, these same strategies are directly responsible for the lack of agricultural sustainability. We can't solve the ecological, social, or economic problems of agriculture today with the same kind of thinking that created them.

We need a new kind of farmer to tackle the challenges of farming today. Sustainable farmers must manage diverse crop and livestock systems in ways that restore soil fertility, manage pests, and sequester solar energy, rather than relying on synthetic fertilizers and pesticides and other fossilenergy-based inputs. Sustainable farmers must manage their farms in ways that reconnect them in positive relationships with their neighbors and their customers. Sustainable farming is inherently management intensive, meaning that it will take more farmers on smaller farms to feed the nation. The food may not be as cheap, but sustainably produced food will be worth paying the full environmental, social, and economic costs. And in order to grow more crops and livestock more sustainably, we also must grow more sustainable farmers.

As stated in the inaugural call for proposals for this journal, "Over the last two decades, a myriad of programs have been started to stem [the loss of farmers]." Some of these programs have met with modest success, such as the USDA Small Farms program. Others have only accelerated the decline, such as those subsidizing beginning farmers in conventional commodity production. Government programs to grow more farmers must be based on thinking very different from thinking of the past.

Today's approach to farm policy probably made sense until around the middle of the last century. The manufacturing sector of the economy was

growing rapidly and good-paying jobs were readily available for most of those who left agriculture. At that time, many of the negative ecological and social consequences of industrial agriculture were unknown. Neither of those conditions exists today. The good-paying manufacturing jobs have gone to other countries. Unemployment is hovering just under 10

percent, with little prospect for ever recovering the good-paying manufacturing jobs of the past. With growing recognition of the negative environmental, social, and public health impacts of industrial agriculture, farm policies of the past no longer make economic or political sense.

The only legitimate justification for government involvement specifically in agriculture is food security. Farm policies since the 1950s have focused on food security through economic efficiency and international trade. Farmers are subsidized to produce feed grains for export while we rely on food imports for security. Food security based on international markets is not real food security, as many countries discovered with the skyrocketing food prices of 2008. The new thinking would focus farm policy on long-run, domestic food security, through restoring the natural fertility of the land and growing farmers committed to stewardship of the land. As Wendell Berry has written, "If the land is to be used well, the people who use it must know it well, must be highly motivated to use it well, must know how to use it well, must have time to use it well, and must be able to afford to use it well." 
How might this kind of thinking reshape farm policy? A quick search of the internet will show that federal, state, and local governments are routinely shelling out subsidies of $\$ 30,000$ to $\$ 50,000$ per private-sector job, in their effort to reduce unemployment. Many of these jobs are not new but rather are jobs relocated from one community to another. The subsidies include direct payments, tax abatements, infrastructure, worker training, and other publicly funded economic incentives. Official government estimates for the current stimulus program exceed $\$ 90,000$ in government funds per job created. Why not subsidize the creation of new, permanent employment for farmers instead? Farm programs could be redirected to create new opportunities for farmers in both rural and urban communities who are committed to staying in those communities and caring for the land. Federal funds budgeted each year for current farm commodity programs could facilitate the creation of at least 400,000 new sustainable farms.

The details of such policies would need to be worked out through a deliberative process involving taxpayers, consumers, and farmers excluding agribusinesses. Perhaps they would come up with a "New Farmstead Act," a program to establish new farms and farmers in both rural and urban communities. Beginning farmers could be given $\$ 50,000$ - a no-interest, nonrecourse government loan — for a down payment on a farm. The farmer would have five to 10 years, depending on the nature of the farming operation, to establish a sustainable, commercial farming operation with at least $\$ 100,000$ in annual sales.

To ensure that farmers are able to "use the land well," the purchase price of the land could not exceed $\$ 500,000$ - about 100 acres of good farmland in the Midwest, a few acres on the urban fringe, or a vacant city lot. In addition, the principle farm operators would have to earn 75 percent of their total income from the farm in order to validate their personal commitment. The purchase would place an agricultural easement on the land, to protect against later sale for development. After a successful "proving up" period, 20 percent of the loan would be written off each year until the loan were erased. If farmers failed to prove up their farmsteads, their land would be sold to another farmer, or to the government, at no more than the original purchase price.

The intent here is not to propose a specific new program, but rather a new way of thinking about farm policy. Regardless of the details, a dramatic rethinking will be necessary if the U.S. is to grow enough new farmers to ensure the nation's food security. 
Journal of Agriculture, Food Systems, and Community Development ISSN: 2152-0798 print / 2152-0801 online www.AgDevJournal.com 